Article

\title{
Should I Stay or Can I Go? Accessible Tourism and Mountain Huts in Gran Paradiso National Park
}

\author{
Riccardo Beltramo $^{1,2, *}$, Stefano Duglio ${ }^{1,2}\left[\right.$ and Giulio Mario Cappelletti ${ }^{3}(\mathbb{C}$ \\ 1 Department of Management, School of Management and Economics, University of Torino, 218bis Corso \\ Unione Sovietica, 10134 Torino, Italy; stefano.duglio@unito.it \\ 2 NatRisk-Interdepartmental Research Centre on Natural Risks in Mountain and Hilly Environments, \\ University of Torino, 218bis Corso Unione Sovietica, 10134 Torino, Italy \\ 3 Department of Economics, Management and Territory, University of Foggia, 11 Via Alberto da Zara, \\ 71121 Foggia, Italy; giulio.cappelletti@unifg.it \\ * Correspondence: riccardo.beltramo@unito.it
}

check for updates

Citation: Beltramo, R.; Duglio, S.; Cappelletti, G.M. Should I Stay or Can I Go? Accessible Tourism and Mountain Huts in Gran Paradiso National Park. Sustainability 2022, 14, 2936. https://doi.org/10.3390/ su14052936

Academic Editor: Nikolaos Boukas

Received: 29 December 2021

Accepted: 24 February 2022

Published: 2 March 2022

Publisher's Note: MDPI stays neutral with regard to jurisdictional claims in published maps and institutional affiliations.

Copyright: (C) 2022 by the authors. Licensee MDPI, Basel, Switzerland. This article is an open access article distributed under the terms and conditions of the Creative Commons Attribution (CC BY) license (https:// creativecommons.org/licenses/by/ $4.0 /)$.

\begin{abstract}
Within the tourism sector, sustainability has been studied widely at different levels and with different lenses. In the last few years, many research activities have been carried out to assess the social dimension of tourism. Under this perspective, scholars have focused on the accessibility of the tourism and hospitality sectors. This study represents the first-ever attempt to assess how tourists' physical handicaps or special needs are considered in a very specific kind of accommodation facility: the mountain hut. To do so, semi-structured interviews were conducted with mountain hut managers about four mountain huts-29\% of all the mountain huts located in Gran Paradiso National Park, the first established Italian protected area. The results underline both strong and critical points. Considering that many mountain huts are located in severe environments (e.g., medium-high altitudes and reachable only on foot), they have limitations in hosting visitors with physical constraints, who, on the other hand, normally do not attend this kind of facility. By contrast, all of the mountain hut managers were able to satisfy visitors with special food needs, for example, vegetarian, vegan or gluten-free, showing their capability to cope with new forms of tourism demands and expectations.
\end{abstract}

Keywords: mountain tourism; hospitality sector; mountain huts; accessibility; natural protected areas

\section{Introduction}

Over the years, the debate on how to protect biodiversity while also conducting economic activities in full respect of the environment has been very strong, and the different, sometimes opposing positions, have not always managed to reach an agreement. The concept of absolute protection of the environment predominated in the 1960s ecological literature, but since the 1980s, the concept of sustainable development has also extended to protecting human needs while always respecting the environment [1,2]. Some authors later highlighted how the environmentalist vision can be combined with that of territorial planning [3], while other authors consider nature as capital, an asset to be valued that can produce ecosystem services and as a heritage usable by society [4]. These ecosystem services can generate a whole series of positive effects for a population in terms of cultural, educational and recreational services [5]. MAB UNESCO [6], drew up an alternative vision envisaging two fundamental distinctions: areas provided for the wilderness and nature reserves. In the first case, natural heritage protection is very strict to preserve endangered plant and animal species. In the second case, however, the use of natural resources by users and the local community is also envisaged, under the supervision of the competent authorities and under certain conditions. Of course, it is necessary to ensure that habitat and species conservation is not endangered by human activities. In this way, the local community can take advantage of numerous forms of profits related to the accessibility 
and use of some services that also generate an economic return and general benefits related to health, social and environmental well-being [7].

This means making protected natural areas accessible to all; however, these areas, precisely because they are not very populated, present access difficulties for people who have motor, sensory and cognitive disabilities. In recent years, sensitivity toward people with special needs has grown, and numerous initiatives have been undertaken to allow everyone to take advantage of the protected natural areas.

The concept of disability has been extended to all types of disabilities, including motor, sensory, cognitive and even dietary requirements. According to the United Nations Convention, Article 30 [8], state parties recognize the right of persons with disabilities to participate on an equal basis with others in cultural life and must take appropriate measures to ensure that persons with disabilities have access to venues for cultural events or services. Therefore, it would be useful to define "tourism for all". It means knowing how to combine the reasons for the tourism business with the ability to know how to respond to a demand for "hospitality" that requires attention, dialogue and technical knowledge.

In Europe, according to the Eurostat study [9], the potential demand for accessible tourism is estimated at about 127.5 million people (with 46 million people with some form of disability plus about 81 million people over 65). Italy has over 3 million disabled people, equal to $5.2 \%$ of the population $[10,11]$. Thus, it is clear that people with disabilities are not a minority and that their numbers are increasing. It is also necessary to consider people who have special needs not attributable to a specific disability, which consequently increases the number of tourists with special needs.

The translation of the concept of sustainable development to the tourism sector dates to the mid-1990s after the announcement of the Charter of Lanzarote [12]. In some ways, the charter represents a starting point of an intense debate that was of interest not only for policymakers, institutions, public opinion and tourism operators but also for practitioners and scholars. The debate led to refining the meaning of sustainable tourism. In accordance with the United Nations Environment Programme (UNEP) and the World Tourism Organization (WTO), it is presently defined as "tourism that takes full account of its current and future economic, social and environmental impacts, addressing the needs of visitors, the industry, the environment and host communities" [13] (p. 12).

Even if some authors consider this definition as lacking practical implications, with the consequential risk of remaining an empty concept $[14,15]$ the statement encompasses all the dimensions of sustainability. Indeed, it takes into account the economic, environmental and social sides of sustainable development and considers all tourism stakeholders as well as its beneficiaries [16-20].

Sustainability in the tourism sector has been studied from different perspectives [21] and measured in terms of both the tourism destination [22,23] and the hospitality sector [24,25].

In doing so, many authors have focused on implementing different tools with qualitative or quantitative indicators [26-28]. However, research is still lacking in terms of evaluating how the hospitality sector considers accessible tourism to mountain areas. In particular, this paper focuses on the most symbolic kind of mountain accommodation facility: the mountain hut.

Therefore, the authors' aim is to fill the aforementioned gap by presenting provisional results on a survey on four mountain huts in Gran Paradiso National Park, the first Italian national park, to explore the managers' viewpoints on whether accessible tourism practices are feasible in this very specific kind of accommodation, in order to answer the following research question: Can tourists with disabilities or special needs be hosted in these very particular facilities?

The paper is organized as follows: Section 2 introduces the conceptual framework used to carry out the study. After the area of investigation is introduced, Section 3 contains the adopted methodology. Section 4 details the results of the study, while Section 5 is devoted to discussing the results. Finally, the conclusion is aimed at presenting the strong points 
of this research and the main limitations while suggesting new avenues of research. This study's approach is consistent with Goals 3 and 10, in particular 10.2, of the 2030 Agenda.

\section{Conceptual Framework}

\subsection{Mountain Tourism}

Mountains are some of the most important tourism destinations worldwide and contribute to both the local and global economy by generating significant revenues $[29,30]$. They play such an important role in tourism because they can meet different tourists' needs and expectations, such as sports activities, leisure, culture or simply relaxation [31].

Consequently, and depending on the mountains' geographical and socioeconomic contexts, mountain tourism may differ significantly by mountain destination, with different implications on the local societies and on the natural environment. Thus, sustainable tourism in mountain areas has become a highly debated issue that has interested scholars, local policymakers, practitioners and citizens, and it has been studied from several perspectives, depending on the specific mountain area.

A fundamental part of the literature focuses on the consequences that climate change will have on the tourism season in winter destinations, for example, ski resorts, in different areas of the world [32,33] and on how these destinations can counteract it $[34,35]$. This theme is sensitive due to the importance and the magnitude of the economic revenue on the local communities.

Other scholars have paid attention to how to measure and monitor sustainable development in mountain tourism destinations in order to highlight the relationship between sustainability and competitiveness [36-38]. Furthermore, in terms of destination management, some studies have provided quantitative approaches to Weaver's model of sustainable destination management $[23,39]$ using a devoted set of indicators $[28,40]$. In considering the hospitality sector and, more precisely, mountain huts, research has paid particular attention to service quality [12] and to the environmental implications of the activities carried out by such facilities [41,42]. To the authors' knowledge, however, no researchers yet have attempted to study the relationship between mountain huts and accessible tourism.

\subsection{Accessible Tourism}

The scientific literature on accessibility in tourist facilities is quite recent and deals with different aspects of the problem. Some scholars have focused on describing the obstacles that disabled people encounter during their experiences as travelers, both in visiting tourist sites [43-45] and in public transport [46]. Some studies highlight the problem of the accessibility of various tourist destinations, particularly protected natural areas $[18,19]$.

An important aspect addressed by many authors is the availability of information. Puhretmair and Buhalis [47] highlight that the availability of information on the level of accessibility of the places and structures to visit is equally important as physical accessibility itself. In particular, Darcy [48] highlights the need among disabled people to identify structures that are accessible and, above all, meet their needs. Instead, Aitchison [49] points out that the lack of information on the accessibility of structures is an obstacle to tourist accessibility. Other authors $[50,51]$ have analyzed the availability and clarity of information on the Web.

Some researchers have provided solutions to improve information use for tourist sites, in particular by making use of apps [52]. Darcy and Dickson [53] suggest an inclusive vision that involves, in a single model, all types of disabilities (temporary and permanent) and all of the stakeholders who are involved in disability, and that satisfies all the needs of disabled people. Nigg and Eichelberger [54] take a similar approach. They affirm that involving all of the actors involved in disability issues is fundamental to implementing forms of tourism that are accessible for all. Sica et al. [14] propose implementing an identifying label to distinguish structures that can support disabled persons, provide easy access and provide specific dedicated services. 


\section{Materials and Methods}

\subsection{The Area of Investigation}

The area of investigation is the Gran Paradiso National Park (GPNP hereafter), in the northwestern Italian Alps. The GPNP was the first Italian park created and was established in 1922 with a king's decree [55]. It is a trans-regional protected area between the two Italian regions of Piedmont and Aosta Valley. In particular, due to its $710.4 \mathrm{~km}^{2}$ of completely mountainous surface, the park encompasses five alpine valleys-three in the Aosta Valley Region (Cogne, Valsavarenche and Rhêmes Valley) and two in the Piedmont Region (Orco and Soana Valleys)_over 13 municipalities and comprising about 9000 residents.

The GPNP represents a hallmark for the territorial development of this mountain area by preserving the mountainous habitat while also promoting sustainable tourism actions and projects. Recent research focusing on all of the mountain municipalities in the Aosta Valley and the Metropolitan City of Torino Provinces [28] has shown the GPNP's role in driving the municipalities toward becoming sustainable tourism destinations.

Figure 1 shows the area of investigation.

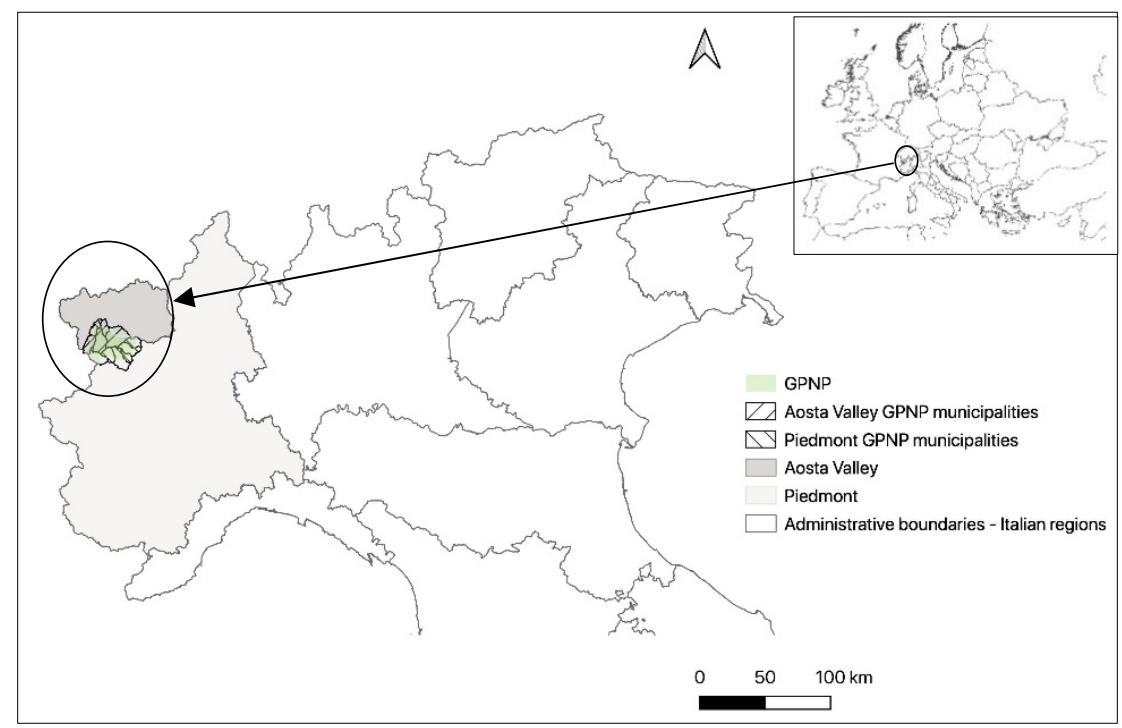

Figure 1. The area of investigation. Source: Internal elaboration from [56] for UE administrative boundaries and [57] for Italian administrative boundaries.

According to the GPNP's statistics, the area has an average of 1,800,000 visitors per year, concentrated in the summer season (690,000 visitors from May to October). The last available data provided by the GPNP, from 2018-before the COVID-19 pandemic crisis-reported some 142,000 arrivals. The park provides 171 accommodation facilities (131 in Aosta Valley and 40 in Piedmont) with 7920 beds (6720 in the Aosta Valley and 1200 in Piedmont). Mountain huts play an important role in this picture, representing 14 accommodation facilities and $10 \%$ of both the hospitality facilities and bed offerings (Table 1).

In accordance with Table 1, 14 mountain huts are within the GPNP's borders-six of those $14(43 \%)$ are located in the Piedmont side of the protected area, whereas eight are in Aosta Valley. Five mountain huts are reachable by car, one by cable car and the remaining $57 \%$ on foot. Eight of the mountain huts are private, four belong to a chapter of the Italian Alpine Club (IAC), one belongs to a climbing club and the last belongs to a municipality. The average altitude is $2256 \mathrm{~m}$ above sea level, which increases to $2574 \mathrm{~m}$ when considering only the Aosta Valley mountain huts. The total number of beds is 767 (602 in Aosta Valley and 165 in Piedmont), while the average number of beds is about 55, which increases to 75 when considering only the Aosta Valley. The visitor profile mostly depends on the mountain huts' locations as compared to the opportunities offered by the surrounding environment. 
Mountain huts reachable by car, for instance, are normally visited by daily tourists aiming to taste mountain recipes and take advantage of the beautiful surrounding environment.

Table 1. Mountain huts in the GPNP.

\begin{tabular}{|c|c|c|c|c|c|}
\hline \multicolumn{6}{|c|}{ Piedmont Region } \\
\hline Name & Valley & Altitude (m) & Owner & Beds & Accessibility \\
\hline Le Fonti Minerali & Orco & 1620 & Private & 20 & By car \\
\hline Massimo Mila & Orco & 1583 & Private & 25 & By car \\
\hline Guido Muzio & Orco & 1670 & IAC Chivasso & 22 & By car \\
\hline Guglielmo Jervis & Orco & 2250 & $\begin{array}{l}\text { IAC Ivrea } \\
\text { "Pontese" }\end{array}$ & 26 & On foot \\
\hline Pontese & Orco & 2217 & $\begin{array}{l}\text { Climbing Club } \\
\text { (Private) }\end{array}$ & 70 & On foot \\
\hline Rosa dei Banchi & Soana & 1650 & $\begin{array}{l}\text { Municipality of } \\
\text { Valprato Soana }\end{array}$ & 2 & Cable car \\
\hline \multicolumn{6}{|c|}{ Aosta Valley Region } \\
\hline Name & Valley & Altitude (m) & Owner & Beds & Accessibility \\
\hline Federico Chabod & Valsavarenche & 2710 & Private & 136 & On foot \\
\hline Tètras-Lyre & Valsavarenche & 2000 & Private & 40 & On foot \\
\hline Vittorio Emanuele II & Valsavarenche & 2732 & IAC Torino & 120 & On foot \\
\hline Savoia & Valsavarenche & 2534 & Private & 50 & By car \\
\hline Città di Chivasso & Valsavarenche & 2604 & Private & 35 & By car \\
\hline Benevolo & Rhêmes & 2285 & Private & 48 & On foot \\
\hline Delle Marmotte & Rhêmes & 2142 & Private & 12 & On foot \\
\hline Vittorio Sella & Cogne & 2588 & IAC Biella & 161 & On Foot \\
\hline
\end{tabular}

Source: Internal elaboration.

Therefore, the tourism sector is enriched by the presence of several local food producers, 20 of which have been included in the Slow Food movement. Indeed, local food products can play an important role in fostering an area's local tourism sector $[58,59]$ because foodstuffs can receive certification with Protected Denomination of Origin (PDO) and, more recently, specific labels, for example, as "Mountain Products". Qualifying the local offerings is also one of the GPNP's goals. Indeed, the park has established its own qualification model, the GPNP Quality label, and issued devoted procedures for different kinds of food and non-local food production, as well as the tourism sector, with the aim of promoting local producers and tourism operators that take care of environmental and social aspects in carrying out their business.

Moreover, the GPNP is carrying out a set of actions to promote accessible tourism. Under the umbrella of the "Un Paradiso Accessibile" (An Accessible Paradise), the park has established a set of mountain paths and accommodations in accordance with the guidelines established by the Norcia Chart. The actions have been extended to the accommodation facilities that have obtained the aforementioned GPNP Quality label [60].

All of these variables were considered when defining the mountain huts to involve in the analysis.

\subsection{Selection Criteria}

The parameters used for identifying the suitable mountain huts included the following aspects:

- Location: The presence of specific local hallmarks or attractions, on which the typology of average visitors depends, was one of the most important parameters for selecting the mountain huts. Indeed, local hallmarks or attractions define the typology of tourists, which can be divided into three main categories: families (day-trippers), hikers and mountaineers.

- Accessibility: The mountain huts are equally distributed between those reachable by car and only on foot. This parameter is fundamental because Italian mountain huts 
are categorized depending on their accessibility (A—reachable by car; B-reachable by cable car; C, D and E-reachable on foot). In order to verify accessible tourism in mountain accommodations, it is important to consider the two main ways of reaching the structure: by car and on foot.

- Mountain hut dimensions, in terms of the number of beds offered.

- Owner: The mountain huts are distributed between those belonging to private entities versus the IAC.

- Main typology of visitors: Mountaineers, hikers and day-trip visitors, as stated above. In evaluating this aspect, it was important to choose mountain huts that only hosted mountaineers, hikers, families and a mix of the categories.

- Tourism labels: Whether the facility has received the GPNP Quality label, which can have repercussions on both the kinds of services offered and their quality levels.

Table 2 summarizes the selected mountain huts whose managers were involved in the study, in accordance with the listed parameters.

Table 2. Mountain huts selected for the survey.

\begin{tabular}{|c|c|c|c|c|c|c|c|c|c|}
\hline Name & Region & Valley & $\begin{array}{l}\text { Altitude } \\
\text { (m) }\end{array}$ & Owner & Beds & Accessibility & Visitor & $\begin{array}{l}\text { Hallmark } \\
\text { /Attraction }\end{array}$ & $\begin{array}{l}\text { GPNP } \\
\text { Label }\end{array}$ \\
\hline Massimo Mila & Piedmont & Orco & 1583 & Private & 25 & By car & Families & $\begin{array}{l}\text { Ceresole } \\
\text { Reale Lake }\end{array}$ & Yes \\
\hline Tètras-Lyre & Aosta Valley & Valsavarenche & 2000 & Private & 40 & On foot & $\begin{array}{c}\text { Families / } \\
\text { Hikers }\end{array}$ & None & No \\
\hline $\begin{array}{c}\text { Vittorio } \\
\text { Emanuele II }\end{array}$ & Aosta Valley & Valsavarenche & 2732 & IAC Torino & 120 & On foot & Mountaineers & $\begin{array}{l}\text { Gran } \\
\text { Paradiso } \\
\text { Peak }\end{array}$ & No \\
\hline Savoia & Aosta Valley & Valsavarenche & 2534 & Private & 50 & By car & $\begin{array}{l}\text { Families / } \\
\text { Hikers }\end{array}$ & $\begin{array}{l}\text { Pian del } \\
\text { Nivolet }\end{array}$ & No \\
\hline
\end{tabular}

Source: Internal elaboration.

Based on the table, the following mountain huts were identified:

1. Massimo Mila: Reachable by car, Massimo Mila mountain hut is located on the border of an artificial lake, which is the most important tourist attraction in the Orco Valley. It is mostly suitable for families and day visitors. The hut obtained the GPNP Quality label and is located at the beginning of the "Il giro lago" (The Lake Tour) accessible path.

2. Tetras Lyre: Located at $2000 \mathrm{~m}$ and reachable on foot in $15 \mathrm{~min}$, Tetras-Lyre mountain hut is frequented mostly by hikers and families who want to experience a mountain environment. It belongs to a private company and can be considered a small size alpine accommodation.

3. Vittorio Emanuele II: Vittorio Emanaule II is the base for climbing Gran Paradiso peak (4019 m), the only "four-thousand" peak completely in Italian territory. It is frequented by mountaineers. Vittorio Emanuele II is a large historic mountain hut in the northwest of the Italian Alps and belongs to the IAC.

4. Savoia: Savoia is located in one of the park's most beautiful environments (Cole de Nivolet) and is reachable by car. It is also a stop for hikers who are traveling the two-week Aosta Valley Alta Via 2 (Haute Route no. 2) trek. Consequently, it is frequented by both hikers and daily visitors. It belongs to a private owner and it can be considered a medium-sized mountain hut.

Thus, there is a balanced distribution between private mountain huts (three of nine$33 \%$ ) and belonging to the IAC (one of four-25\%). We selected a mountain hut in the Orco Valley because this valley is the most touristed one. Le Fonti Minerali, Massimo Mila and Guido Muzio are located in the same municipality (Ceresole Reale), but we chose Massimo Mila because it is the only one close to Ceresole Reale Lake. For Aosta Valley, the huts were selected according to their accessibility, types of guests, presence of hallmarks and dimensions. 
Figure 2 details the locations of the accommodation facilities along with the Italian administrative boundaries (in grey) and the GPNP's boundaries (in green).

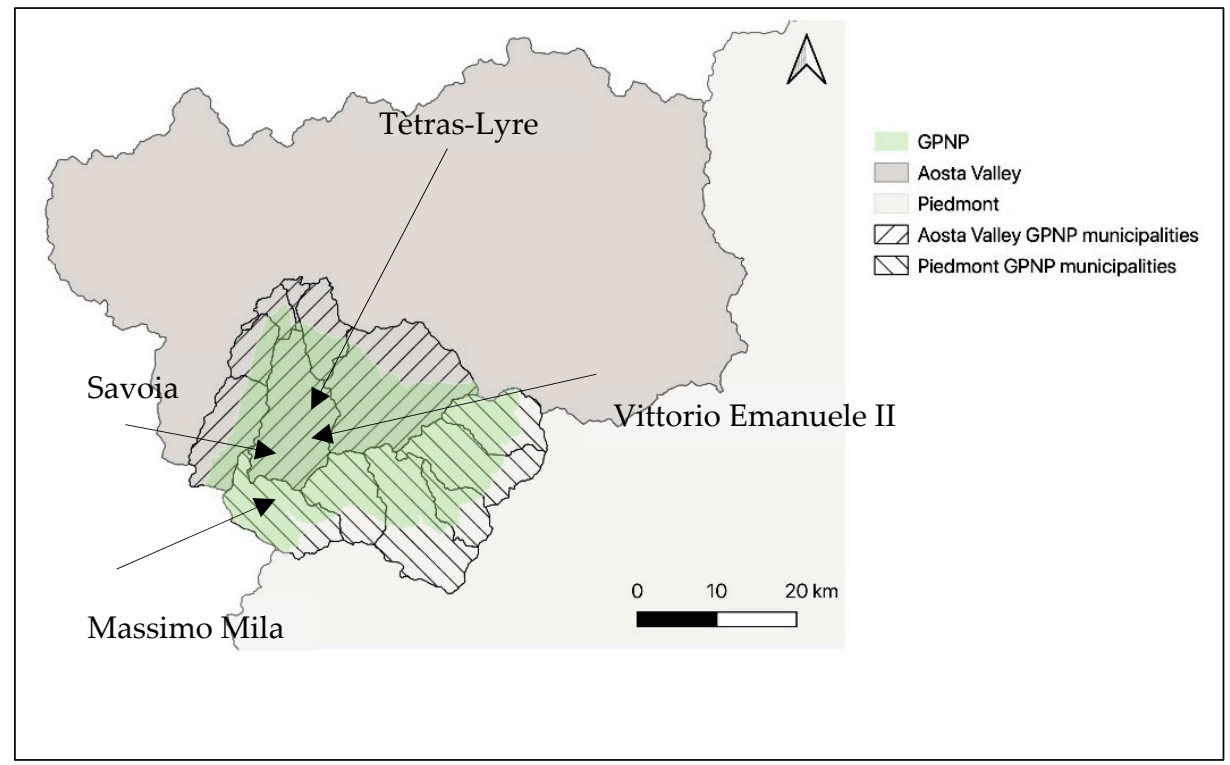

Figure 2. Location of the mountain huts.

Source: Internal elaboration from [57] for Italian administrative boundaries and [61] for the GPNP's boundaries.

Therefore, although the sample comprises four mountain huts, it can be considered representative of all of the GPNP's mountain accommodations. Indeed, the selected mountain huts represent $29 \%$ of the total mountain huts in the area and are consistent with the different typologies of mountain shelters (by car vs. on foot). Moreover, the mountain huts are near the principal tourist attractions of the area (Gran Paradiso Peak, Ceresole Lake and Col de Nivolet) welcoming the two main kinds of tourists: mountaineers and families.

\subsection{Methodology}

The study was carried out using individual semi-structured interviews with all four of the identified mountain hut managers $[62,63]$. Semi-structured interviews are a kind of interview with predefined questions but a certain degree of liberty given to the interviewer in determining unplanned questions, in accordance with how the interview itself evolves. This methodology can be used to collect open-ended data and understand the interviewee's beliefs and ideas about a specific topic of interest [64]. Indeed, semi-structured interviews have some advantages as compared to both structured interviews and completely unstructured interviews: the former helps to keep the focus on the selected topic capture in-depth information and stimulate two-way communication. On the other hand, semi-structured interviews can provide only qualitative information and are time-consuming, and the role of a highly-skilled interviewer becomes essential to carry out the analysis. The managers were first contacted by phone to introduce the study's aims and goals to them before scheduling a meeting to perform the interview. The authors conducted the interviews at the mountain huts during a typical mountain hut manager's workday in July 2021, in accordance with the following timetable:

1. Tetras-Lyre and Vittorio Emanuele II: 21 July 2021.

2. Massimo Mila and Savoia: 26 July 2021.

The interviews lasted between 1 and $2 \mathrm{~h}$ and included a set of open questions to understand how the managers were facing the issues. Two interviewers were involved in each interview. Each interviewer took notes separately, and the evidence from both interviewers was compared to identify the main aspects. Furthermore, the interviews were 
the basis for compiling an internal questionnaire containing 11 main fields on the following issues: information, external and internal areas, connectivity, restaurant, rooms, common rooms, toilettes, corridors and personnel. The fields are reported in Table 3 in further detail. Annex S1 contains the draft of the proposed questions (see the Supplementary Materials section).

Table 3. Fields considered by the interviews.

\begin{tabular}{lc}
\hline \multicolumn{1}{c}{ Field } & Number of Questions \\
\hline Information transparency & 2 \\
Area outside the structure & 4 \\
Entrance of the structure & 4 \\
Connectivity & 1 \\
Restaurant room and barroom & 2 \\
Administration of meals & 2 \\
Room dedicated to disabled guests & 6 \\
Corridors and passageways & 5 \\
Common bathrooms & 2 \\
Evaluation of the satisfaction of disabled guests & 1 \\
and accompanying persons & 1 \\
Personnel &
\end{tabular}

\section{Results}

The results are organized by presenting the main outcomes derived from each mountain hut that was involved in the research process.

\subsection{Tètras-Lyre Mountain Hut}

Tètras-Lyre mountain hut [65] (Figure 3) is easily reachable on foot within 15 min by a path or $5 \mathrm{~min}$ by a dirt road from the main parking area of Valsavarenche. The dirt road is closed to the public, so only authorized visitors, such as the mountain hut manager and his staff, can reach the accommodations by car. Thus, following the Italian classification for mountain huts, Tètras-Lyre falls within category C, i.e., reachable on foot. However, if necessary for reasons such as physical handicaps, the manager will pick tourists up at the parking area and drive them to the hut.

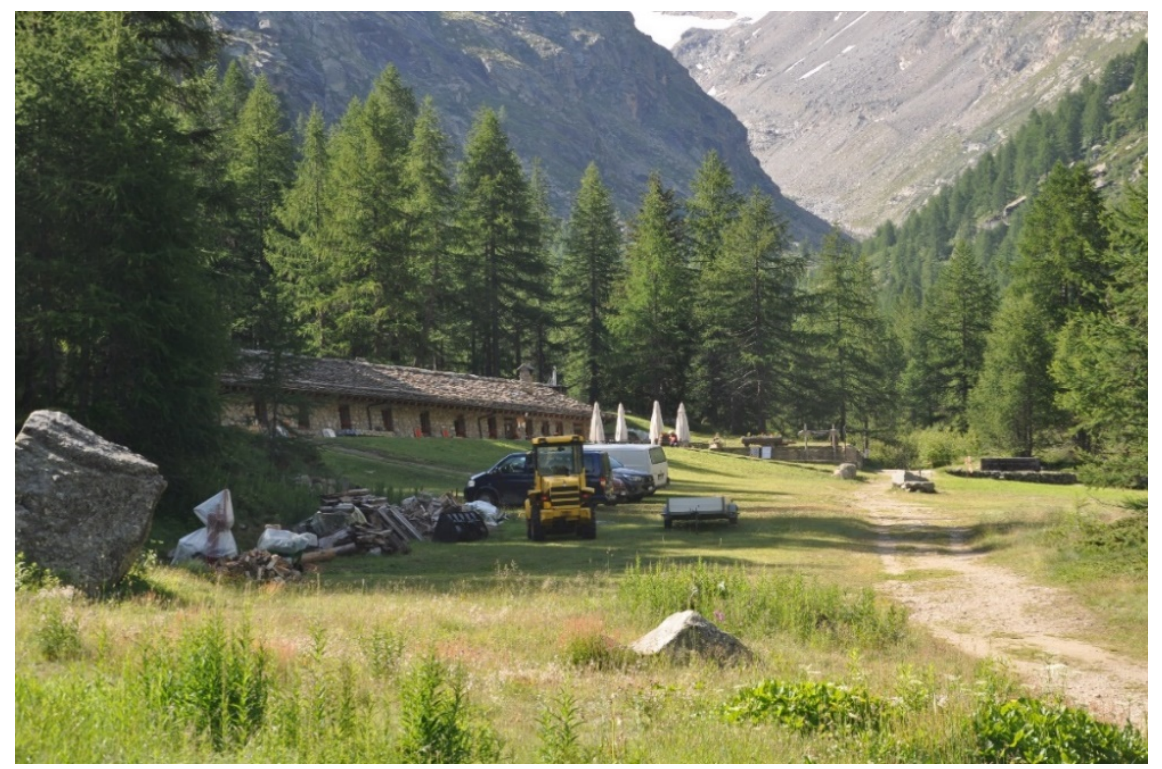

Figure 3. Tètras-Lyre Mountain hut. 
According to the manager, Tètras-Lyre is mostly frequented by day tourists that come to the mountain hut to experience typical Aosta Valley cuisine and its local food products.

The original structure was a local farm, which was converted into an accommodation facility 10 years ago. In doing so, the manager paid attention to creating comfortable common spaces and rooms. As this concerns physical accessibility, therefore, visitors in wheelchairs can easily access the restaurants and the common bathrooms. The corridors do not present barriers or obstacles that can impede access and the rooms are generally spacious.

However, the manager underlined that due to the typical kind of accommodation (the way to reach it), it is rare for the hut to welcome visitors with physical disabilities, especially for the night. This is the main reason why the mountain hut does not have a devoted bedroom.

Regarding special dietary requirements, according to Tètras-Lyre's manager, who has 30 years of experience in managing mountain huts, the number of tourists with allergies or food intolerances has increased in the last decade and now represents around 15-20\% of the guests. Even if people with celiac disease are only a minor portion of them, it is not uncommon for visitors to ask for gluten-free dishes or recipes. The mountain hut offers dedicated menus for these individuals, and at the beginning of the opening season, the mountain hut manager restocks the hut with enough products for people with food intolerances or allergies (e.g., biscuits for breakfast or pasta). However, it is problematic to estimate the number of visitors with special food needs and thus difficult to completely avoid food waste.

\subsection{Vittorio Emanuele Mountain Hut}

At 2732 m above sea level, the Vittorio Emanuele II mountain hut [66] (Figure 4) is a historic mountain accommodation in the Italian Alps and is reachable only on foot in about $2 \mathrm{~h}$ and $30 \mathrm{~min}$ (accommodation type: D). Vittorio Emanuele II, which was built in the 1930s, belongs to the Torino chapter of the IAC and specifically serves mountaineers and ski-mountaineers. The lodge is open in the summer and spring. Indeed, it is possible to climb some of the most beautiful peaks in Gran Paradiso National Park from the hut, in particular Gran Paradiso Peak, at $4061 \mathrm{~m}$.

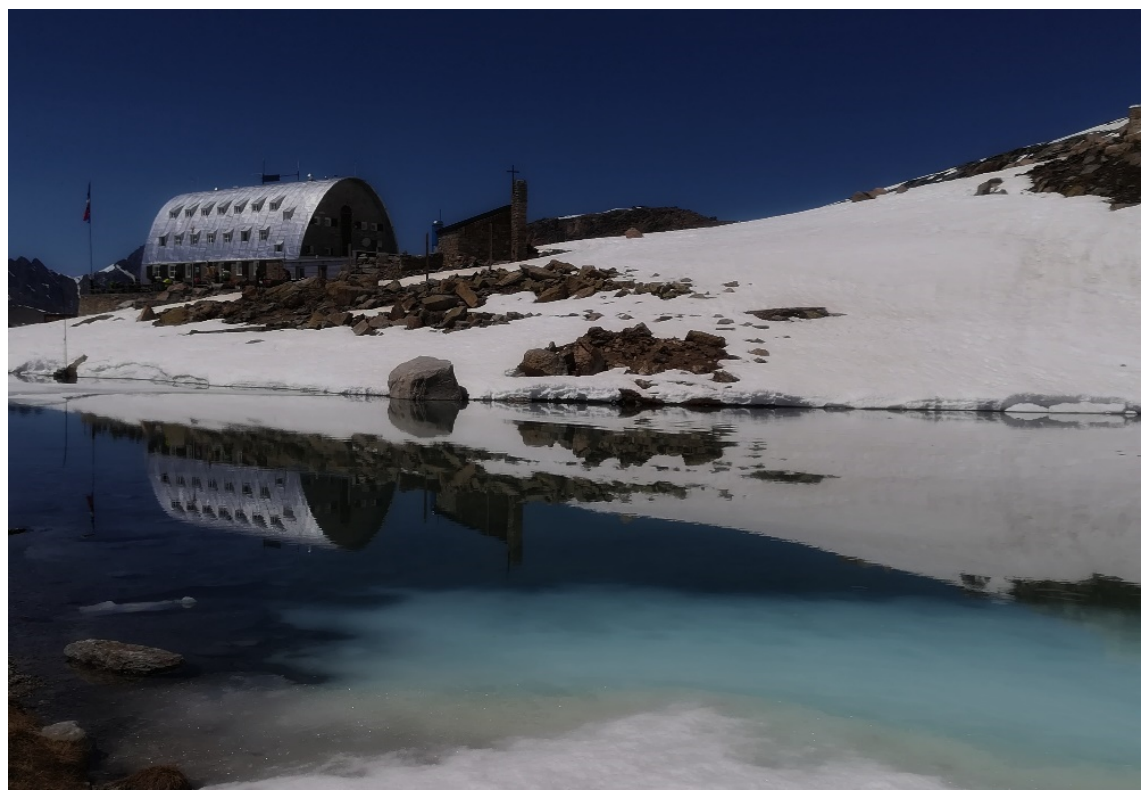

Figure 4. Vittorio Emanuele II Mountain hut (courtesy of the manager).

Therefore, as support for climbing purposes, the mountain hut was not specifically equipped for people with physical handicaps and does not have any devoted rooms or 
bathrooms for guests with disabilities. The hut offers 120 beds in rooms with four or five bunk beds each or in a dormitory as well as eight showers in common bathrooms. Notably, due to the geographical and natural constraints of the environment where the hut is located, no guests with physical disabilities can reach the accommodations.

One member of the management team is the same person who also manages the Tètras-Lyre mountain hut; thus, the internal procedures for visitors with special food and beverage needs are the same for the two mountain huts, even though the available spaces for the kitchens are different. However, the manager believes that even if it is possible to confirm that the number of mountaineers and hikers with food allergies or intolerances has increased over the years, this phenomenon is less significant as compared to the Tètras-Lyre lodge.

Although it is impossible to offer complete and dedicated menus for people with special food needs, due to the different locations of the huts resulting in different means and costs for food supplies (the supply of raw materials is provided only by helicopter), the mountain hut is able to offer dishes specifically for people with special dietary needs (vegetarian, celiac disease, etc.). The manager decided to supply food and ingredients for guests with special needs at the beginning of each season, even if in different quantities, given the different kinds of customers and the transportation constraints.

\subsection{Massimo Mila Mountain Hut}

Massimo Mila mountain hut [67] (Figure 5) is located in the Piedmont side of the GPNP at Ceresole Reale (1583 m), next to the eponymous lake. The accommodation is reachable by car; consequently, it is classified as type $\mathrm{A}$, in accordance with the mountain hut classification. Therefore, Massimo Mila is similar to restaurants and hotels, in terms of visitors and tourism offerings. The hut particularly relies on weekend tourists who, after experiencing the different tourism opportunities provided by the surrounding lake environment (e.g., biking, bouldering and hiking), normally have lunch at Massimo Mila.

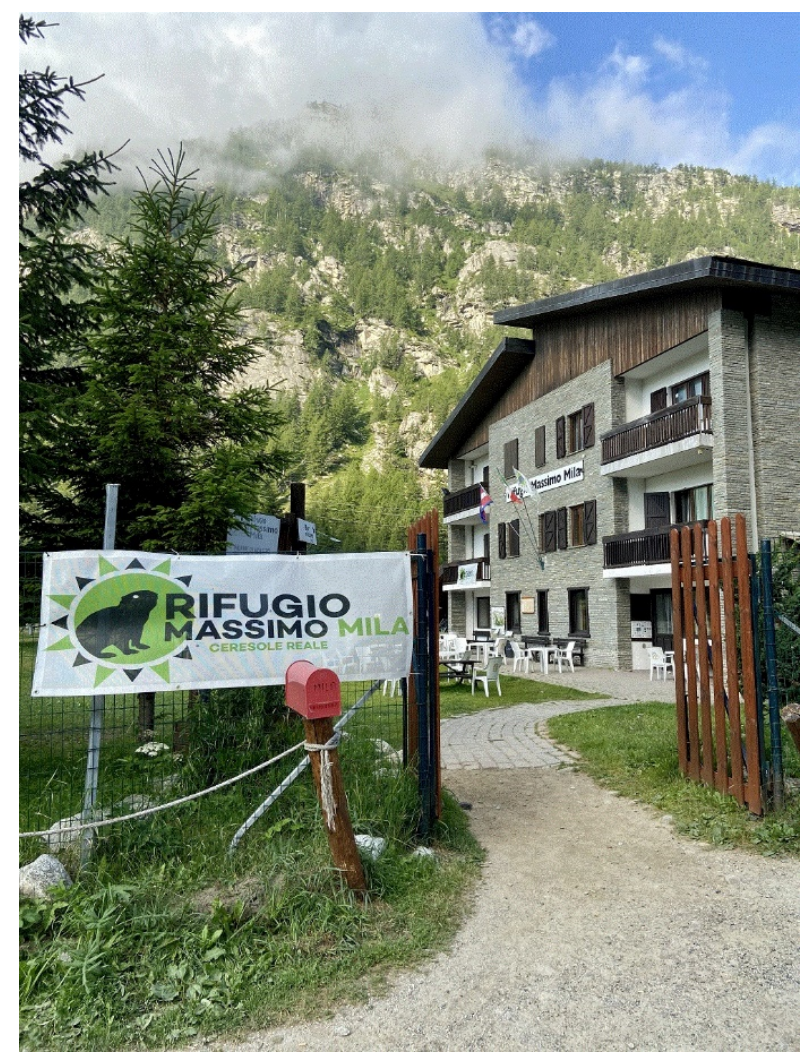

Figure 5. Massimo Mila Mountain hut. 
The hut's restaurant and common toilet areas are easily accessible for people with physical handicaps, being free from architectural barriers. In particular, there is a toilet equipped for visitors with wheelchairs or other physical constraints. The main parking area is outside the mountain hut at an adjacent lot and is managed by the Municipality of Ceresole Reale. The area is also equipped with a toilet for visitors with disabilities, although there are no specific spaces for them to park their cars. The mountain hut has a small private parking zone available only to guests.

Massimo Mila's manager underlined the significance of guests with special dietary requirements, who presently account for about $15-20 \%$ of the tourists. The manager proposes special dishes for vegetarian or vegan tourists, and the hut can prepare glutenfree dishes for celiac guests with this need, as reported on the home page of Massimo Mila's website. Due to the efforts by the management team to improve the quality of the hut's offerings, Massimo Mila obtained the quality label provided by the GPNP.

\subsection{Savoia Mountain Hut}

The Savoia mountain hut [68] (Figure 6) is reachable by car. It is located $2534 \mathrm{~m}$ above sea level and is a destination for two different kinds of visitors. The first is "hit-and-run" tourists, mostly concentrated during the July and August weekends, who, after short treks in the surroundings of the mountain hut, aim to experience typical dishes. This tourist component is mostly formed by families and couples. On the other hand, because the Savoia hut is the starting point for several treks and peaks, it is also popular among hikers, who spend the night.

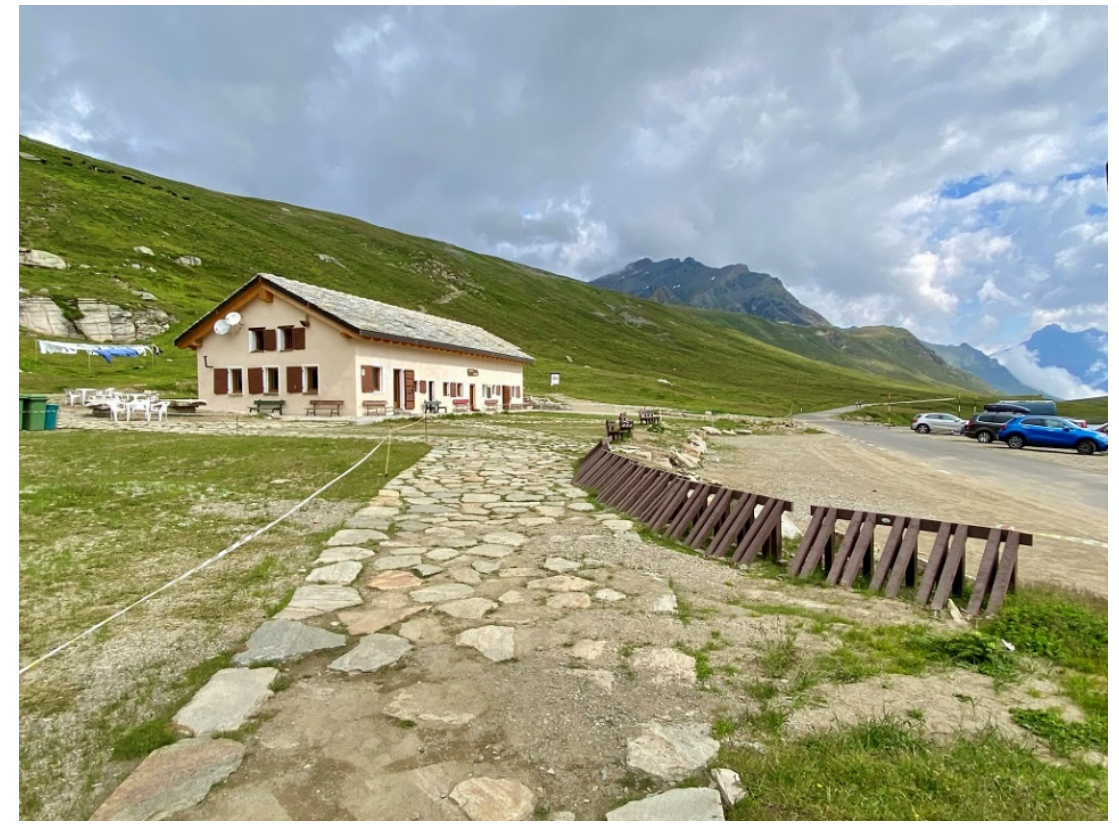

Figure 6. Savoia Mountain hut.

The common rooms (the restaurant and common toilets) are accessible to tourists with physical impediments. As for the Mila mountain hut, the parking area and the common bathrooms next to the parking zone are managed externally by the local administration, the Municipality of Valsavarenche. Because only hikers sleep in the mountain hut, the management has never had to cope with people with disabilities.

In terms of food offerings, Savoia's policies were the same as those of the other mountain huts involved in this exploratory study. Although the mountain hut's manager stated that guests with intolerances, allergies or special dietary requirements were not a particularly significant guest component, the accommodation is equipped to serve them by proposing devoted menus and dishes. 


\section{Discussion}

Although mountain huts were born as facilities specifically devoted to facilitating accessibility to the so-called "high lands" and as a basis for climbing the surrounding peaks, the guests have changed over time due to changes in the concept of mountain tourism, in terms of both demand and tourist offerings. Together with mountaineers and hikers, new types of tourists with different kinds of needs and expectations are experiencing the facilities, and some of the accommodations have become easier to reach over time.

Two of the four mountain accommodations profiled in the study were classified as Type A (reachable by car), one was easily accessible, and one accommodation was specifically devoted to welcome mountaineers, the main reason why mountain huts were originally created. Consequently, mountain hut managers must face challenges deriving from having different kinds of guests as compared to the past, by tuning their offerings to these new tourists' needs and expectations, as already pointed out in previous studies on quality service of mountain huts [12,41].

The results of the interviews with the mountain hut managers show a certain capacity among them to adapt to the new context, which depends on the location, the hut's accessibility and the kinds of guests. The mountain huts that are reachable by car had all of the necessary installations for welcoming visitors with physical impediments. On the other hand, historical mountain huts that can be reached only on foot have more difficulties in rearranging their spaces to accommodate visitors with physical disabilities because they were planned and built for a specific kind of purpose and for guests who do not need such requirements.

By contrast, when considering special dietary requirements, all of the interviewed mountain hut managers affirmed that they changed their operations for providing dishes by considering the new context. In this specific case, all of the interviewees clearly pointed out that the number of guests with special food requests, for example, vegetarian and vegan visitors, has increased over time, representing, in some cases, an important percentage in terms of tourism, at around one of every five visitors. This new trend shows an inverse correlation with the ease of reaching the facility and with the typology of the mountain hut. Type A facilities (reachable by car) have an important share of visitors with special food needs, whereas Types C, D and E accommodations (reachable only on foot and created essentially for climbing purposes) seem to have a lower impact from such guests. The manager of Massimo Mila mountain hut specified the possibility of catering to guests with special dietary needs on its Internet site. In any case, the mountain hut managers affirmed that they had no particular difficulties in dealing with vegetarian or vegan tourists.

Within this picture, persons who suffer from celiac disease are a minority of guests; however, the mountain hut managers had adopted special arrangements to host them safely. However, the managers' operations are guided partly by the typology of the mountain hut Types C, D and E mountain huts such as Vittorio Emanuele II-normally located at medium and high altitudes-have limited ability to cope with their limited exploitable spaces for rooms, including bathrooms and kitchens. Doubling the kitchen work surfaces to completely avoid possible food contamination is impossible and cannot be fully guaranteed. The mountain hut managers tried to face these new consumers by purchasing gluten-free products (pasta, biscuits for breakfast, etc.) at the beginning of the summer season.

To summarize, it is possible to point out convergence points and differences among the mountain huts. Regardless of their hut's location, classification and service typologies, all of the mountain hut managers underlined the importance of tourists with special dietary requirements, for whom the managers diversified the meals according to the guests' needs. The presence of persons with physical disabilities mostly depends on the environmental characteristics and geographical constraints of the area where the facilities are located and it is extremely rare in mountain huts reachable on foot. However, mountain hut managers have shown the ability to host and welcome people with special requests in the past, to provide a pleasant tourism experience. 
The last aspect worth underlining is the fact that only one structure out of the four involved in the study makes use of the GPNP Quality service label.

\section{Conclusions}

Sustainable tourism encompasses all pillars of the sustainability paradigm: the economy, environment and society. The social aspect of sustainable tourism must be considered in terms of positive outcomes, not only on local societies and the preservation of the host communities' cultural heritage but also from the tourists' perspective. The opportunity to offer tourism experiences for the greatest possible number of people falls within this vision, and applying accessible tourism criteria allows people with special needs or constraints to live a tourism experience.

Due to geographical and physical constraints, mountain areas are an interesting environment for assessing methods and mechanisms with which to foster the accessibility of tourism activities. Moreover, considering mountain huts-the most representative mountain accommodation facilities that are critical to manage- -helps with understanding both the strong and critical points in hosting people with special needs in extreme management conditions.

The exploratory results deriving from this provisional study, based on four semistructured interviews with mountain hut managers, highlight both strong and critical points. First, considering the particular environment in which many of the mountain huts are located - at medium or high altitudes, in severe environments and reachable only by foot-Types C, D and E mountain huts may have limitations in hosting visitors with physical constraints. This does not mean that these categories of accommodations have never hosted tourists with physical disabilities, but they do not have special features for hosting such tourists, simply because people with physical disabilities do not stay at such accommodations. When such guests do, however, mountain hut managers have always shown their ability to welcome and host these guests. Type A mountain huts, by contrast, are equipped to host people with physical disabilities in both common and personal rooms.

On the other hand, however, and considering accessibility from a wider perspective, all of the mountain hut managers affirmed that they had become used to hosting visitors with special dietary requirements, who now represent an important proportion of their customers. In this specific case, the mountain hut managers demonstrated their capacity to change their operative processes, habits and behaviors in accordance with a new and potentially challenging market context.

Returning to the research question that provides the title to this contribution- "Should I stay or can I go?" - the answer, according to our preliminary analysis, is "you may go". "May" because, still, for mountain activities, it is always necessary to be aware of the environment and the often severe context by contacting the mountain hut manager, who will provide all of the necessary information for experiencing the mountain hut life.

As with all research activities, this preliminary study contains some limitations, which also can be considered as future research avenues. The most important limitation is that the sample consisted of only four mountain huts. Yet, although the number of accommodations involved may seem limited, the research activity was carried out in a specific mountain area-the GPNP, the first Italian national park — that represents $29 \%$ of all mountain huts in the area, and the sample was representative of two of the Italian classifications of mountain huts. Furthermore, to the authors' knowledge, this is the first attempt to analyze and study accessible tourism for such accommodation establishments.

Thus, although this study must be considered exploratory, it can be a starting point for future research activities focused on analyzing the state of the art of this topic more comprehensively by considering a larger sample of mountain accommodation facilities.

Supplementary Materials: The following supporting information can be downloaded at: https: / / www.mdpi.com/article/10.3390/su14052936/s1, Annex S1: Questionnaire for mountain huts. 
Author Contributions: Conceptualization, R.B., S.D. and G.M.C.; methodology, R.B., S.D. and G.M.C.; investigation, R.B. and S.D.; data curation, R.B., S.D. and G.M.C.; writing-original draft preparation, R.B., S.D. and G.M.C.; writing-review and editing, R.B., S.D. and G.M.C. All authors have read and agreed to the published version of the manuscript.

Funding: This publication was funded by the "E-Parks-Environmental and Administrative Knowledge Networks for a Better Tourist Attractiveness in Protected Natural Areas" research projectInterreg V-A Greece-Italy Programme, MIS CODE 5003237 INTERREG Greece-Italy program, from December 2018-December 2021.

Institutional Review Board Statement: Not applicable.

Informed Consent Statement: The interviewee consent was waived due to the fact that the research project does not provide for the processing of personal data and data do not concern any information relating to an identified or identifiable natural person.

Data Availability Statement: Data available on request, please contact the corresponding author.

Acknowledgments: Heartfelt thanks are due to the Managers of Tètras-Lyre, Vittorio Emanuele II, Massimo Mila and Savoia Mountain huts for participating in the study.

Conflicts of Interest: The authors declare no conflict of interest.

\section{References}

1. World Conservation Strategy: Living Resource Conservation for Sustainable Development. Available online: https:/ /www.iucn. org/content/world-conservation-strategy-living-resource-conservation-sustainable-development (accessed on 28 December 2021).

2. Brundtland, G.H. Our Common Future: Report of the World Commission on Environment and Development; United Nations: New York, NY, USA, 1987.

3. Magnaghi, A. Il Territorio Degli Abitanti. Società Locali e Autosostenibilità; Zanichelli: Bologna, Italy, 1998.

4. Dale, A.P.; Taylor, N.; Lane, M.B. Social Assessment in Natural Resource Management Institutions; CSIRO Publishing: Melbourne, Australia, 2001; ISBN 978-0-643-06558-1.

5. Millennium Ecosystem Assessment. Ecosystems and Human Well-Being: Current State and Trends; World Resources Institute: Washington, DC, USA, 2005; Available online: https:/ / www.millenniumassessment.org/documents/document.766.aspx.pdf (accessed on 20 December 2021).

6. UNESCO. A New Roadmap for the Man and the Biosphere (MAB) Programme and Its World Network of Biosphere Reserves; United Nations Educational, Scientific and Cultural Organization: Paris, France, 2017; ISBN 978-92-3-100206-9.

7. Setola, N.; Marzi, L.; Torricelli, M.C. Accessibility Indicator for a Trails Network in a Nature Park as Part of the Environmental Assessment Framework. Environ. Impact Assess. Rev. 2018, 69, 1-15. [CrossRef]

8. United Nations. United Nations Convention on the Rights of Persons with Disabilities; United Nations: New York, NY, USA, 2006.

9. EUROSTAT. Disability Statistics. Available online: https://ec.europa.eu/eurostat/statistics-explained/index.php?title= Disability_statistics (accessed on 28 December 2021).

10. ISTAT. Conoscere il Mondo Della Disabilità: Persone, Relazioni e Istituzioni; Istituto Nazionale di Statistica: Rome, Italy, 2019; ISBN 978-88-458-2005-2.

11. ENAT. ENAT Annual Report 2020; European Network for Accessible Tourism: Bruxelles, Belgium, 2021.

12. Duglio, S.; Beltramo, R. Quality Assessment in the Italian Mountain Huts. Eur. J. Tour. Res. 2014, 8, 115-142. [CrossRef]

13. UNEP; WTO. Making Tourism More Sustainable: A Guide for Policy Makers; United Nations Environment Programme; World Trade Organization: Geneva, Switzerland, 2005; ISBN 92-807-2507-6.

14. Sica, E.; Sisto, R.; Bianchi, P.; Cappelletti, G.M. Inclusivity and Responsible Tourism: Designing a Trademark for a National Park Area. Sustainability 2021, 13, 13. [CrossRef]

15. Sisto, R.; Cappelletti, G.M.; Bianchi, P.; Sica, E. Sustainable and Accessible Tourism in Natural Areas: A Participatory Approach Curr. Issues Tour. 2021, 1-18. [CrossRef]

16. Cappelletti, G.M.; Bianchi, P.; Russo, G.; Strizzi, C. Accessibility and Facility of the Disabled: The Consorzio Di Bonifica Montana Del Gargano and Parco Nazionale Del Gar-Gano Cases Studies; SKRIPTA International: Budapest, Hungary, 2019; pp. 337-346.

17. Cappelletti, G.M.; Di Noia, A.E.; Nicoletti, G.M. Best Practices for People with Disabilities Adopted in Italian National Parks; Association of Economists and Managers of the Balkans: Belgrade, Serbia, 2019; pp. 179-186.

18. Bianchi, P.; Cappelletti, G.M.; Sica, E.; Sisto, R. Stakeholder Involvement to Improve Accessibility in a Protect Natural Area: A Case Study; Franco Angeli: Milano, Italy, 2020; pp. 53-61.

19. Di Noia, A.E.; Nicoletti, G.M.; Cappelletti, G.M. Italian Protect Natural Areas Registrered Under EMAS: Role of Interested Parties; Franco Angeli: Milano, Italy, 2020; pp. 281-288.

20. Bianchi, P.; Cappelletti, G.M.; Mafrolla, E.; Sica, E.; Sisto, R. Accessible Tourism in Natural Park Areas: A Social Network Analysis to Discard Barriers and Provide Information for People with Disabilities. Sustainability 2020, 12, 9915. [CrossRef] 
21. Qian, J.; Shen, H.; Law, R. Research in Sustainable Tourism: A Longitudinal Study of Articles between 2008 and 2017. Sustainability 2018, 10, 590. [CrossRef]

22. Mihalič, T. Environmental Management of a Tourist Destination: A Factor of Tourism Competitiveness. Tour. Manag. 2000, 21, 65-78. [CrossRef]

23. Weaver, D.B. A Broad Context Model of Destination Development Scenarios. Tour. Manag. 2000, 21, 217-224. [CrossRef]

24. Ozturkoglu, Y.; Sari, F.O.; Saygili, E. A New Holistic Conceptual Framework for Sustainability Oriented Hospitality Innovation with Triple Bottom Line Perspective. J. Hosp. Tour. Technol. 2019, 12, 39-57. [CrossRef]

25. Gardetti, M.A.; Torres, A.L. Sustainability in Hospitality: How Innovative Hotels Are Transforming the Industry; Green Leaf Publishing Books: New York, NY, USA; Taylor and Francis: New York, NY, USA, 2017; ISBN 978-1-351-28536-0.

26. Lew, A.A.; Ng, P.T.; Ni, C.; Wu, T. Community Sustainability and Resilience: Similarities, Differences and Indicators. Tour. Geogr. 2016, 18, 18-27. [CrossRef]

27. Kristjánsdóttir, K.R.; Ólafsdóttir, R.; Ragnarsdóttir, K.V. Reviewing Integrated Sustainability Indicators for Tourism. J. Sustain. Tour. 2018, 26, 583-599. [CrossRef]

28. Duglio, S.; Letey, M. The Role of a National Park in Classifying Mountain Tourism Destinations: An Exploratory Study of the Italian Western Alps. J. Mt. Sci. 2019, 16, 1675-1690. [CrossRef]

29. United Nations Environment Program. Tourism and Mountains: A Practical Guide to Managing the Environmental and Social Impacts of Mountain Tours; UNEP: Nairobi, Kenya, 2007; ISBN 978-92-807-2831-6.

30. Debarbieux, B.; Oiry Varacca, M.; Rudaz, G.; Maselli, D.; Kohler, T.; Jurek, M. Tourism in Mountain Regions: Hopes, Fears and Realities; Debarbieux, B., Oiry Varacca, M., Rudaz, G., Maselli, D., Kohler, T., Jurek, M., Eds.; Department of Geography and Environment, University of Geneva: Geneva, Switzerland; Centre for Development and Environment, University of Bern: Bern, Switzerland, 2014; ISBN 978-2-88903-027-9.

31. Richins, H.; Johnsen, S.; Hull, J.S. Overview of mountain tourism: Substantive nature, historical context, areas of focus. In Mountain Tourism: Experiences, Communities, Environments and Sustainable Futures; Richins, H., Hull, J.S., Eds.; CABI: Wallingford, CT, USA, 2016; pp. 1-12, ISBN 978-1-78064-460-8.

32. Steiger, R. The Impact of Snow Scarcity on Ski Tourism: An Analysis of the Record Warm Season 2006/2007 in Tyrol (Austria). Tour. Rev. 2011, 66, 4-13. [CrossRef]

33. Pickering, C.M.; Buckley, R.C. Climate Response by the Ski Industry: The Shortcomings of Snowmaking for Australian Resorts. Ambio 2010, 39, 430-438. [CrossRef]

34. Dawson, J.; Scott, D. Managing for Climate Change in the Alpine Ski Sector. Tour. Manag. 2013, 35, 244-254. [CrossRef]

35. Hennessy, K.J.; Whetton, P.H.; Walsh, K.; Smith, I.N.; Bathols, J.M.; Hutchinson, M.; Sharples, J. Climate Change Effects on Snow Conditions in Mainland Australia and Adaptation at Ski Resorts through Snowmaking. Clim. Res. 2008, 35, 255-270. [CrossRef]

36. Fuchs, M.; Peters, M.; Weiermair, K. Tourism Sustainability Through Destination Benchmarking Indicator Systems: The Case of Alpine Tourism. Tour. Recreat. Res. 2002, 27, 21-33. [CrossRef]

37. Jurigová, Z.; Lencsésová, Z. Monitoring System of Sustainable Development in Cultural and Mountain Tourism Destinations. J. Compet. 2015, 7, 35-52. [CrossRef]

38. Paunović, I.; Jovanović, V. Implementation of Sustainable Tourism in the German Alps: A Case Study. Sustainability 2017, 9, 226. [CrossRef]

39. Weaver, D.B. Organic, Incremental and Induced Paths to Sustainable Mass Tourism Convergence. Tour. Manag. 2012, 33, 1030-1037. [CrossRef]

40. Della Lucia, M.; Franch, M. The Effects of Local Context on World Heritage Site Management: The Dolomites Natural World Heritage Site, Italy. J. Sustain. Tour. 2017, 25, 1756-1775. [CrossRef]

41. Beltramo, R.; Duglio, S. A Methodology for the evaluation of mountain huts in the context of sustainable tourism. A study on 40 facilities in Piedmont region. In Changing Paradigms in Sustainable Mountain Tourism Research. Problems and Perspectives; Erich Schmidt Verlag: Berlin, Germany, 2016; pp. 267-282. ISBN 978-3-503-16768-5.

42. Stubelj Ars, M.; Bohanec, M. Towards the Ecotourism: A Decision Support Model for the Assessment of Sustainability of Mountain Huts in the Alps. J. Environ. Manag. 2010, 91, 2554-2564. [CrossRef] [PubMed]

43. McIntosh, A.J. The Hidden Side of Travel: Epilepsy and Tourism. Ann. Tour. Res. 2020, 81, 102856. [CrossRef]

44. Nursanty, E.; Anwar, L.M. Accessible Tourism the Tourism without Barriers in Architecture and Tourism Design. In Proceedings of the Planning in the Era of Uncertainty, Changsha, China, 4-5 March 2013.

45. Hennig, S.; Sattler, T.; Wasserburger, M.; Wasserburger, W.W. How to Improve Accessibility of Natural Areas: About the Relevance of Providing Information on Accessible Services and Facilities in Natural Areas; CORP-Competence Center of Urban and Regional Planning: Essen, Germany, 2015; Volume 2, pp. 803-812.

46. Yau, M.K.; McKercher, B.; Packer, T.L. Traveling with a Disability: More than an Access Issue. Ann. Tour. Res. 2004, 31, 946-960. [CrossRef]

47. Pühretmair, F.; Buhalis, D. Accessible Tourism Introduction to the Special Thematic Session. In Computers Helping People with Special Needs; Miesenberger, K., Klaus, J., Zagler, W., Karshmer, A., Eds.; Springer: Berlin/Heidelberg, Germany, 2008 ; pp. 969-972.

48. Darcy, S. Setting a Research Agenda for Accessible Tourism; Sustainable Tourism Cooperative Research Centre (STCRC): Gold Coast, QLD, Australia, 2006; ISBN 1920704973.

49. Aitchison, C. Exclusive Discourses: Leisure Studies and Disability. Leis. Stud. 2009, 28, 375-386. [CrossRef] 
50. Domínguez Vila, T.; Alén González, E.; Darcy, S. Website Accessibility in the Tourism Industry: An Analysis of Official National Tourism Organization Websites around the World. Disabil. Rehabil. 2018, 40, 2895-2906. [CrossRef]

51. Gonçalves, M.J.A.; Camarinha, A.P.; Abreu, A.J.; Teixeira, S.; da Silva, A.F. Web Accessibility in the tourism sector: An analysis of the most used websites in Portugal. In Advances in Tourism, Technology and Smart Systems; Rocha, Á., Abreu, A., de Carvalho, J.V., Liberato, D., González, E.A., Liberato, P., Eds.; Springer: Singapore, 2020; pp. 141-150.

52. Mayordomo-Martínez, D.; Sánchez-Aarnoutse, J.-C.; Carrillo-de-Gea, J.M.; García-Berná, J.A.; Fernández-Alemán, J.L.; GarcíaMateos, G. Design and Development of a Mobile App for Accessible Beach Tourism Information for People with Disabilities. Int. J. Environ. Res. Public. Health 2019, 16, 2131. [CrossRef]

53. Darcy, S.; Dickson, T.J. A Whole-of-Life Approach to Tourism: The Case for Accessible Tourism Experiences. J. Hosp. Tour. Manag. 2009, 16, 32-44. [CrossRef]

54. Nigg, J.J.; Eichelberger, S. Sustainable Product Development for Accessible Tourism: Case Studies Demonstrating the Need for Stakeholder Collaboration. Sustainability 2021, 13, 11142. [CrossRef]

55. Ministero dell'Ambiente Regio Decreto-Legge 3 Dicembre 1922, n. 1584 (in Gazzetta Ufficiale, 13 Dicembre 1922, n. 291). Decreto Convertito in Legge 17 Aprile 1925, n. 473 (in Gazzetta Ufficiale, 5 Maggio 1925, n. 104)-Costituzione Di Un «Parco Nazionale» Presso Il Gruppo Del Gran Paradiso. Available online: http:/ / www.minambiente.it/normative/regio-decreto-legge-3-dicembre1922-n-1584-gazzetta-ufficiale-13-dicembre-1922-n-291 (accessed on 20 December 2021).

56. Maps for Europe. Available online: https:/ / eurogeographics.org/maps-for-europe/ (accessed on 20 November 2021).

57. Confini Delle Unità Amministrative a Fini Statistici. Available online: https://www.istat.it/it/archivio/222527 (accessed on 20 November 2021).

58. Duglio, S.; Bonadonna, A.; Letey, M.; Peira, G.; Zavattaro, L.; Lombardi, G. Tourism Development in Inner Mountain Areas-The Local Stakeholders' Point of View through a Mixed Method Approach. Sustainability 2019, 11, 5997. [CrossRef]

59. Duglio, S.; Bonadonna, A.; Letey, M. The Contribution of Local Food Products in Fostering Tourism for Marginal Mountain Areas: An Exploratory Study on Northwestern Italian Alps. Mt. Res. Dev. 2022, 42, R1-R10. [CrossRef]

60. Parco Nazionale Gran Paradiso an Accessible Paradise. Available online: http://www.pngp.it/en/visit-park/accessible-park (accessed on 20 December 2021).

61. Cartografia Confini Del Parco. Available online: http://www.pngp.it/ente-parco/cartografia-confini-del-parco (accessed on 20 November 2021).

62. Kallio, H.; Pietilä, A.-M.; Johnson, M.; Kangasniemi, M. Systematic Methodological Review: Developing a Framework for a Qualitative Semi-Structured Interview Guide. J. Adv. Nurs. 2016, 72, 2954-2965. [CrossRef] [PubMed]

63. Klandermans, B.; Staggenborg, S. Methods of Social Movement Research; University of Minnesota Press: Minneapolis, MN, USA, 2002; ISBN 978-0-8166-3594-8.

64. DeJonckheere, M.; Vaughn, L.M. Semistructured Interviewing in Primary Care Research: A Balance of Relationship and Rigour. Fam. Med. Community Health 2019, 7, e000057. [CrossRef]

65. REFUGE DU TĖTRAS LYRE. Available online: www.rifugiotetraslyre.it/it/ (accessed on 28 December 2021).

66. Rifugio Vittorio Emanuele II. Available online: www.rifugiovittorioemanuele.com (accessed on 28 December 2021).

67. Rifugio Massimo Mila. Available online: www.rifugiomila.it/it/ (accessed on 28 December 2021).

68. Rifugio Savoia. Available online: www.rifugiosavoia.com/ (accessed on 28 December 2021). 